\title{
Value Added Tax in Poland - Basis of Functioning and its Efficiency
}

\author{
By Olga Palczewska*
}

The aim of this article is to present the basis of functioning of VAT in Poland as well as to examine its efficiency. The paper consists of three parts. The first part deals with the most important theoretical aspects of VAT in the analyzed country, including design issues and small-scale taxpayers treatment. Then, the VAT revenue to government revenue ratio is examined and compared with other European countries. In the next part of the article, the efficiency of VAT in Poland between 2004 and 2012 is analyzed. Using VRR as a measure it has been proved that during the analyzed period a significant amount of potential VAT was not collected. It suggests that there is a potential for raising additional revenue by improving the VAT performance in Poland. There are various different ways of improving VAT performance in Poland which is then discussed.

Keywords: Efficiency, Poland, Small-scale taxpayer, Tax preferences, Value added $\operatorname{tax}$.

\section{Introduction}

Tax regime is among the areas of key interest for each government, and its structure is equally important for business entities as taxation is a direct government intervention in the financial resources of its citizens. The intervention can be direct or indirect. If the direct taxation cannot be successfully extended, then governments will impose indirect taxes on consumption. One of taxes charged on goods and services is the Value added $\operatorname{tax}$ (VAT).

As defined by the European Council, VAT is a general consumption tax levied on goods and services in proportion to their prices, regardless of the length of the production and distribution chain preceding the imposition of the tax. VAT is calculated on the price of products or services using the tax rate that generally applies to a given product or service, and is chargeable on each transaction throughout the production and distribution process, whereby its amount is reduced by the tax amount charged at the preceding stages. By such consumption taxation mechanism the price distortion is avoided, which otherwise could take place if individual transactions between enterprises were taxed without providing the possibility of deducting the tax charged at preceding stages of the production and distribution process. The VAT system is most transparent and neutral when tax is charged in as general manner as possible. The term "general" means that VAT covers any kind of activities in connection with production and distribution of goods and provision of services.

${ }^{*}$ PhD Student, Poznan University of Economics, Poland. 
It further means that VAT should be capable of being levied on as many products and services as possible (Głuchowski 2004: 206).

A much more general definition of VAT has been provided by Shenk and Oldman (2007: 30). According to them, VAT is a general term for multi-stage taxes levied on added value generated by enterprises at each stage of the process of production and distribution of goods and services. Although generally in nature, the above definition describes the most important attributes of VAT, i.e. that it is multi-staged and charged on the value added. They further emphasized that the exact meaning of the above term depends on specific arrangements taken by individual countries, including the method of determining the tax liability or the extent of tax exemptions.

\section{Value Added Tax in Poland - Design Issues}

In Poland, VAT is called the "tax on goods and services" and has been in effect since 1993. It is regulated by the Polish Value-Added Tax Act of 11 March 2004 (hereinafter: the VAT Act) and is based on the provisions of Directive 2006/112/EC (hereinafter: the Directive) on the common system of value added tax.

Polish VAT is imposed on the supply of goods and the provision of services in Poland, the export of goods, the import of goods into Poland, intraCommunity acquisition of goods and intra-Community supply of goods (Article 5 of the VAT Act). Poland uses a standard VAT rate of $23 \%$ and two reduced rates of 5 and $8 \%$. Reduced rate is imposed on supply of certain medicines and foods as well as on hotel and catering services.

As it can be seen in the Graph 1 the Polish standard VAT rate is among the highest in the EU. The average VAT rate for the EU in 2015 was $21.6 \%$, i.e. $1.4 \mathrm{pp}$ less than in Poland. Such a high VAT rate may create demand barriers and adversely affect the efficiency of VAT collection.

Graph 1. Standard Rate in the EU in 2015

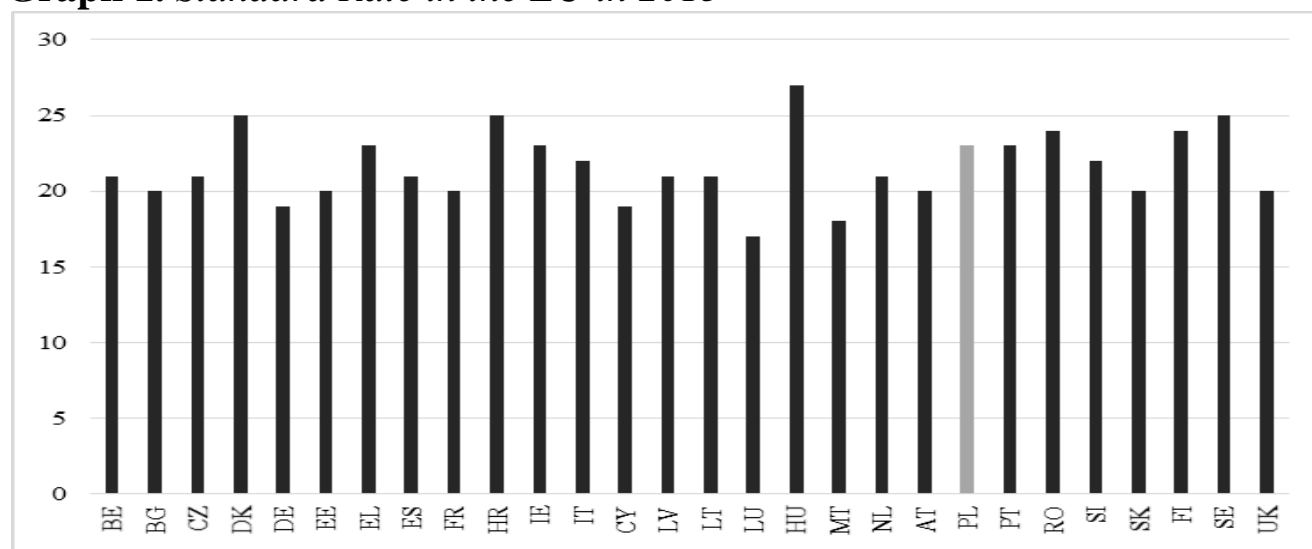

Source: European Commission, 2015. 


\section{VAT and Small Enterprises}

Registration of an enterprise for VAT purposes is not always obligatory and entrepreneurs may benefit from certain preferences in this regard. Preferences are usually offered to small enterprises in order to enable them to reduce costs related to the fulfilment of their fiscal obligations. According to Article 281 of the VAT Directive, the Member States which might encounter difficulties in applying the normal VAT arrangements to small enterprises, by reason of the activities or structure of such enterprises, may, subject to such conditions as they may set, and after consulting the VAT Committee, apply simplified procedures for charging and collecting VAT. However, as the EU has not provided any specific arrangements, the measures actually used by individual countries differ considerably. Arrangements mainly used in Poland include subject exemptions and quarterly settlements and are considered relatively narrow in scope as compared to other EU countries (Hybka 2013: 584).

Among the preferences envisaged in the VAT Act is the subject exemption from VAT, which can be applied by the taxpayers whose turnover in the preceding fiscal year did not exceed PLN 150,000 (EUR 38,000) (Article 113.1 of the VAT Act). Regarding the taxpayers who launch their business during a fiscal year, the turnover value is calculated in proportion to the number of days from when their business started until the end of the fiscal year. It should be noted that, due to lack of specific regulations, the upper limit of the annual net turnover which gives the right to VAT exemption varies considerably between the EU Member States. In 2015, in the EU Member States where the subject VAT exemption was available, the upper limit of the annual net turnover that entitles to subject exemption was between DKK 50,000 (EUR 6,700) in Denmark to GBP 82,000 (EUR 114,000) in Great Britain (VATlive). Some of the Members States, including among others Spain, Malta, and the Netherlands, decided not to apply such exemption. The reason may be that, although the subject exemptions may reduce the tax collection costs due to reduced number of taxpayers, applying an upper annual net turnover giving right to the personal VAT exemption may discourage small enterprises from increasing their scale of operations.

In Poland, according to Article 113.2 of the VAT Act, the turnover shall not include:

1. intra-Community supply of goods and distance selling from and within the territory of Poland,

2. the supply of goods for consideration and the provision of services for consideration, which have been exempt from tax, except for: transactions connected with immovable property, insurance services, transactions concerning currencies, bank notes and coins used as legal tender, services of management of, among others, investment funds and investment funds' investment portfolios, employee pension schemes and lending services, 
3. the supply of goods for consideration, which goods - pursuant to the income tax laws - are declared by a taxpayer as depreciable/amortisable tangible or intangible fixed assets.

Further, in Poland - the same as in the majority of the EU countries choosing the subject VAT exemption is optional, which means that a taxpayer who benefits from the subject exemption may relinquish the exemption right subject to filing a written notification with the head of the tax office before the beginning of the month on which the taxpayer chooses not to be eligible for the exemption, or, in case of taxpayers who start their business during the fiscal year, before the day of their first transaction subject to taxation. Using the exemption again is only possible by no earlier than after one year starting from the end of the year when the exemption right was relinquished. The analyzed exemption is voluntarily relinquished mainly due to the fact that large enterprises usually give preference to the business partners who are VAT taxpayers, as such large enterprises cannot deduct the input tax charged on the purchase of goods and services from enterprises exempt from VAT.

The taxpayers who have decided to use the exemption right must then fulfil certain obligations. First, they have to keep a sales register that enables us to determine if and when a taxpayer exceeds the turnover limit giving right to the VAT exemption. Second, in case of sales to natural persons who do not carry out any business activity, the taxpayers are obliged - after the limit of PLN 20,000 is exceeded - to register sales using a fiscal cash register.

It must be noted that the legislator imposed certain restrictions on using the above tax preference. Namely, some groups of entities are excluded from the right to the personal exemption. Pursuant to Article 113.13 of the VAT Act, the following entities, among others, are not entitled to the subject VAT exemption:

1. the taxpayers who supply goods made of precious metals (or which comprise such metals), subject to excise duty, buildings or structures or their parts, construction sites and new means of transport,

2. the entities who provide legal, advisory or jewellery services,

3. the entities whose legal address is not within the territory of Poland.

Special attention should be given to the issue of not granting the personal exemption to the entities whose legal address is not within the territory of Poland. It means that a taxpayer, benefiting from the personal exemption, who provides services (for which the place of taxation normally is the customer's legal address) to an entity from another member state, will have to charge the tax right from the first transaction.

The subject exemptions are subject to much controversy. On one hand - as already mentioned above - VAT taxpayers give preference to the business partners who are also active VAT taxpayers, because only then they can deduct the input VAT. Another controversy as to the subject exemption for small enterprises is that it affects tax competition between the enterprises exempt from, and subject to, VAT regarding sales to natural persons or to entities 
exempt from tax. A taxpayer who is exempt from VAT does not pay the tax compliance costs, i.e. he sells goods and services without charging VAT. Therefore prices for such goods and services may be higher than net (before tax) prices of goods and services offered by entities subject to taxation, but still lower than their gross (after tax) prices. As a consequence, the entities exempt from VAT are more competitive than entities subject to VAT with regard to sales of goods and services to the entities who are not VAT taxpayers (i.e. natural persons who do not carry out any business activity) or who benefit from the personal or transaction-related exemption. Such entities cannot deduct the input tax so therefore they would always look for the lowest possible final price. This issue is of particular importance for the entrepreneurs whose annual net turnover is only slightly higher that the upper limit giving right to the personal exemption. Moreover, exempting a particular group of entities from VAT is a negation of the principle that VAT should be of general application. The above issue of unequal treatment may be eliminated by abolishing the personal exemption, however it would result in much higher VAT collectionrelated costs. Abolishing the personal exemption may further result in small enterprises being forced to join the black economy.

Another tax preference available for small enterprises is a cash accounting method for VAT settlements. It may be used by small enterprises which have been defined in the VAT Law as entities whose turnover (including tax) did not exceed, in the precedent fiscal year, the PLN equivalent of EUR 1,200,000 (Article 2.13 of the VAT Act). Further, small enterprises also comprise the taxpayers who run brokerage enterprises, manage the investment funds, who are agents or service contractors or other persons who provide services similar in nature, except for commission services - provided that fee or other form of remuneration for their services (including tax) in the precedent fiscal year did not exceeded the PLN equivalent of EUR 45,000. The corresponding amounts are converted using the average EUR exchange rate published by the National Bank of Poland on the first working day of the October of the precedent fiscal year, rounded to PLN 1,000.

The cash accounting method for VAT settlements means a deferral of liability to tax. As a general rule, the tax liability arises when goods or services are delivered. In case of the cash accounting method, the tax liability arises only when payment is fully or partially made by the customer (Article 21 of the VAT Act). A taxpayer is therefore obliged to pay tax only when he actually collects money from a given transaction. However, the legislator imposed a restriction regarding delivery of goods or services to entities who are not VAT taxpayers. In this specific situation, the tax liability arises when payment is fully or partially received but no later than on the 180th day from when the product or service was delivered. So it may happen that a taxpayer will have to pay tax despite not having received payment, however - as compared to those who settle their VAT liabilities under general rules - he has an additional 6 months do pay the tax.

Under the cash accounting method, the term for deducting VAT from purchase invoices is different. Under general tax rules, the output tax can be 
reduced by the input tax when the tax liability arises on the part of the seller and when the buyer receives an invoice, while in the cash accounting method the reduction can be made only on the date when the invoice is paid. Moreover, a taxpayer who uses the cash accounting method pays VAT on a quarterly basis.

\section{VAT Efficiency in Poland}

One of the key criteria to assess taxes by the government is the tax efficiency which means ensuring regular and reliable incomes necessary for the government to fulfil its public duties (Sullivan 1965). VAT is considered as a stable and reliable source of budget revenues. According to Cnossen (1991: 2), VAT is the best ever indirect tax for the fiscal efficiency purposes. VAT accounts for more than $20 \%$ of the global tax revenues and plays an important role as a public finance stabilizer (Boroselli 2011: 5).The practical importance of VAT is reflected in the relation of VAT revenues to the total tax revenues. For example, the above relation in the OECD countries increased from 11.2\% in 1985 to $19.2 \%$ in 2009, which reflects the growing fiscal efficiency of VAT (OECD 2012: 44).

\section{VAT as a Source of Budget Revenues in Poland}

In Poland, VAT is one of the key budget revenues. According to the Table 1 , during the analysed period the relation of revenues from VAT to total budget revenues was in average $40 \%$. The total budget revenues increased from PLN 156,281 in 2004 to PLN 287595 in 2012, followed by the increase in VAT revenues from PLN 62,263 to PLN 120,000. It should be noted that budget revenues growth rate and the VAT revenues growth rate usually differ from the GDP growth rates. The above means that the general economic situation is not the only element that affects the budget and VAT revenues in Poland, which are also materially affected by the structure of the tax and the scope of exemptions.

Table 1. State Budget Revenues, VAT Revenues and their Growth in Years 2004-2012 in Poland

\begin{tabular}{|c|c|c|c|}
\hline Year & $\begin{array}{c}\text { State Budget Revenues } \\
\text { (in mIn PLN) }\end{array}$ & $\begin{array}{c}\text { VAT Revenues } \\
\text { (in PLN) }\end{array}$ & $\begin{array}{c}\text { State Budget to VAT } \\
\text { Revenues Ratio }\end{array}$ \\
\hline $\mathbf{2 0 0 4}$ & $156,281.2$ & $62,263.2$ & $39.8 \%$ \\
\hline $\mathbf{2 0 0 5}$ & $179,722.2$ & $75,401.0$ & $41.9 \%$ \\
\hline $\mathbf{2 0 0 6}$ & $197,639.8$ & $84,439.5$ & $42.7 \%$ \\
\hline $\mathbf{2 0 0 7}$ & $228,952.5$ & $96,349.8$ & $42.1 \%$ \\
\hline $\mathbf{2 0 0 8}$ & $281,892.1$ & $101,782.7$ & $36.1 \%$ \\
\hline $\mathbf{2 0 0 9}$ & $274,183.5$ & $99,454.7$ & $36.3 \%$ \\
\hline $\mathbf{2 0 1 0}$ & $250,302.8$ & $107,880.3$ & $43.1 \%$ \\
\hline $\mathbf{2 0 1 1}$ & $273,144.4$ & $119,300.0$ & $43.7 \%$ \\
\hline $\mathbf{2 0 1 2}$ & $287,595.1$ & $120,000.7$ & $41.7 \%$ \\
\hline
\end{tabular}

Source: Supreme Audit Office 2004-2012. 
VAT is one of the main sources of revenues not only in Poland but also in other EU Member States. The figures in the Table 2 show that, in years 20042012, the VAT revenue to tax revenue ratio was $31.1 \%$ on a yearly average. The ratio level for Poland was usually above the EU average.

Table 2. VAT Revenue to Tax Revenue in EU in 2004-2012 (in \%)

\begin{tabular}{|c|c|c|c|c|c|c|c|c|c|}
\hline Item & 2004 & 2005 & 2006 & 2007 & 2008 & 2009 & 2010 & 2011 & 2012 \\
\hline Belgium & 22.4 & 22.6 & 22.9 & 23.5 & 23.0 & 24.0 & 23.9 & 23.6 & 23.4 \\
\hline Bulgaria & 44.2 & 47.5 & 47.8 & 41.1 & 44.5 & 42.4 & 44.7 & 43.7 & 45.6 \\
\hline Czech Republic & 34.1 & 34.1 & 32.4 & 31.5 & 35.8 & 37.1 & 37.8 & 36.9 & 37.2 \\
\hline Denmark & 20.4 & 20.2 & 21.2 & 21.6 & 21.4 & 21.6 & 21.1 & 21.2 & 21.0 \\
\hline Germany & 29.0 & 28.7 & 28.1 & 29.8 & 30.0 & 31.8 & 32.2 & 31.5 & 30.9 \\
\hline Estonia & 38.0 & 42.6 & 44.1 & 42.3 & 39.3 & 39.3 & 41.8 & 41.3 & 41.2 \\
\hline Ireland & 28.7 & 29.3 & 28.4 & 28.5 & 30.0 & 28.5 & 28.6 & 25.6 & 25.6 \\
\hline Greece & 33.7 & 33.3 & 34.0 & 34.9 & 34.8 & 32.1 & 35.8 & 33.1 & 30.9 \\
\hline Spain & 26.7 & 26.9 & 26.0 & 23.5 & 24.1 & 21.7 & 27.1 & 26.7 & 26.0 \\
\hline France & 26.7 & 26.7 & 26.3 & 26.5 & 26.2 & 27.0 & 26.8 & 25.8 & 24.9 \\
\hline Croat & 48.6 & 48.7 & 47.7 & 46.7 & 47.3 & 46.4 & 47.9 & 48.4 & 50.7 \\
\hline Italy & 20.7 & 21.4 & 21.2 & 20.6 & 20.3 & 19.5 & 21.6 & 21.4 & 20.0 \\
\hline Сур & 33.2 & 34.2 & 34.6 & 31.5 & 34.3 & 34.4 & 34.4 & 32.0 & 34.1 \\
\hline Latv & 35.2 & 37.7 & 39.5 & 37.7 & 32.0 & 33.0 & 35.0 & 35.6 & 36.5 \\
\hline Lithuania & 32.5 & 35.0 & 36.2 & 38.5 & 37.8 & 41.4 & 47.1 & 48.7 & 47.0 \\
\hline Luxer & 22.7 & 22.7 & 22.3 & 22.3 & 23.4 & 24.7 & 23.8 & 24.8 & 25.7 \\
\hline Hungary & 34.9 & 33.9 & 30.7 & 30.2 & 29.3 & 31.8 & 33.8 & 35.7 & 36.1 \\
\hline Malta & 28.6 & 30.2 & 29.2 & 26.8 & 28.3 & 27.8 & 28.3 & 29.0 & 28.4 \\
\hline Netherlands & 30.9 & 29.2 & 29.5 & 29.7 & 29.4 & 28.7 & 29.3 & 29.2 & 30.2 \\
\hline Austria & 27.8 & 28.7 & 28.0 & 27.7 & 27.3 & 29.1 & 29.0 & 28.3 & 28.3 \\
\hline Poland & 36.8 & 37.0 & 37.0 & 36.3 & 34.7 & 36.1 & 37.4 & 38.3 & 35.9 \\
\hline Portugal & 34.8 & 36.6 & 36.0 & 34.9 & 34.9 & 32.3 & 34.9 & 34.9 & 36.4 \\
\hline Romania & 36.9 & 44.3 & 42.1 & 41.9 & 42.2 & 38.0 & 42.1 & 44.7 & 43.7 \\
\hline Slovenia & 35.4 & 35.2 & 35.0 & 35.1 & 36.4 & 36.1 & 36.5 & 37.2 & 36.5 \\
\hline Slovakia & 42.2 & 42.2 & 42.6 & 38.3 & 40.1 & 41.5 & 40.2 & 41.8 & 38.5 \\
\hline Finland & 26.7 & 27.2 & 27.5 & 26.9 & 27.1 & 28.9 & 28.6 & 29.0 & 29.6 \\
\hline Swe & 23.5 & 23.3 & 22.9 & 23.8 & 24.5 & 25.1 & 26.0 & 25.4 & 25.2 \\
\hline United King & 23.7 & 22.7 & 22.0 & 22.1 & 20.7 & 20.4 & 22.6 & 24.8 & 25.3 \\
\hline Iceland & 30.0 & 29.7 & 29.6 & 28.1 & 26.8 & 26.1 & 25.8 & 25.3 & 25.5 \\
\hline Norway & 23.8 & 22.7 & 22.6 & 24.1 & 21.7 & 24.3 & 23.9 & 23.1 & 23.5 \\
\hline Switzerland & 17.8 & 17.4 & 17.3 & 17.1 & 16.7 & 16.3 & 16.8 & 17.0 & 17.6 \\
\hline Average & 30.7 & 31.3 & 31.1 & 30.4 & 30.5 & 30.6 & 31.8 & 31.7 & 31.7 \\
\hline
\end{tabular}

Source: Eurostat database. ${ }^{1}$

For example, in 2012 the ratio value for Poland was $35.9 \%$, i.e. 4.3 pp higher than the EU average. In 2012, the highest ratio value was reported for Croatia $(50.7 \%)$ and the lowest ratio value was reported for Switzerland $(17.6 \%)$.

\footnotetext{
${ }^{1}$ Retrieved from http://goo.gl/SD2z9s.
} 


\section{Efficiency Ratios}

One of the ratios that may be used to measure the efficiency of VAT is the so called "efficiency ratio" - the ratio of VAT revenue to GDP, divided by the standard VAT rate. It shows by how many percentage points the VAT revenue to GDP ratio will change if the standard VAT rate rises by one percentage point (Ebrill et al. 2001: 40-41). The higher the ratio value the higher the efficiency of the tax.

Another ratio to measure the VAT efficiency, based on consumption instead of GDP, is the so called "C-efficiency ratio", used by IMF. Its formula is (Keen 2013: 6):

where:

$$
\mathrm{E}^{\mathrm{C}}=\frac{\mathrm{V}}{\tau_{\mathrm{s}} \mathrm{C}}
$$

$E^{C}$ - C-efficiency ratio,

$\mathrm{V}$ - revenue from value added tax,

$\tau_{\mathrm{s}}$ - standard VAT rate,

C - consumption expenditure.

The above ratio compares the VAT revenue generated at the current tax structure and the VAT revenue that could be generated if the tax is charged at a uniform rate equal to the standard VAT rate on all goods and services without any exemptions (Keen 2013: 6). Any value other than one means that taxation is not efficient. The greater the deviation, the bigger the VAT inefficiency. The ratio value below one suggests that the fiscal VAT efficiency could be increased if the tax base is extended by eliminating exemptions and reduced tax rates. From the purely economic point of view, the highest fiscal VAT efficiency can be achieved by applying a uniform rate to a wide tax base, so called "pure VAT regime". The EC ratio is used in global statistics, which enable comparative analyses between individual countries. But this measure has flaws. It may be overstated, e.g. as the result of a cascade effect of the exempt of financial intermediation services from VAT or of including used goods into the consumption base (OECD 2012: 109). The ratio value above one may therefore mean that numerous transaction-related VAT exemptions (which prevent the output tax from being reduced by input tax) are applied at the beginning of the production and distribution chain. Exempting final goods and services (i.e. offered directly to natural persons) from VAT results in reduced VAT revenues.

The C-efficiency ratio can be interpreted in two different ways. For example, if the ratio value is 0.6 at the standard rate of $15 \%$, then - assuming that the consumption is constant - it means that (Keen 2013: 10):

1. if a uniform tax rate of $15 \%$ is charged on all goods and services, then the VAT revenue will increase by approximately $66.7 \%$ : 


$$
\frac{1-E^{C}}{E^{C}}=\frac{1-0,6}{0,6}=0,667
$$

2. if a uniform rate of $9 \%$ is charged on all goods and services, then the VAT revenue will be equal to the current revenue:

$$
\tau_{S} \cdot E^{C}=0,15 \cdot 0,6=0,09
$$

The equivalent of the above ratio, used for the purposes of OECD statistics, is the VRR ratio, the formula of which is (OECD 2014: 95):

$$
\mathrm{VRR}=\frac{\mathrm{VR}}{\mathrm{Br}}
$$

where:

VRR - actual VAT revenues,

$\mathrm{B}$ - potential tax base,

$r$ - standard VAT rate.

As it is pointed out in the OECD report (2014: 96) since there is no standard assessment of the potential tax base for all OECD countries methodological difficulty may arise. In order to avoid this problem final consumption expenditure as measured in the national accounts is used.

The VRR measures the difference between the VAT revenue actually collected and what would theoretically be raised if all the conditions were met jointly:

1. standard VAT rate is applied to the entire potential tax base,

2. "pure" VAT regime is applied,

3 . all revenue is collected.

The VRR in Poland is among the lowest in the OECD. Each year it has been below the OECD average, which means that significant amount of potential VAT was not collected (Graph 2). It suggests that there is a potential for raising additional revenue by improving the VAT performance in Poland. 
Graph 2. VAT Revenue Ratio in Poland in 2004-2012

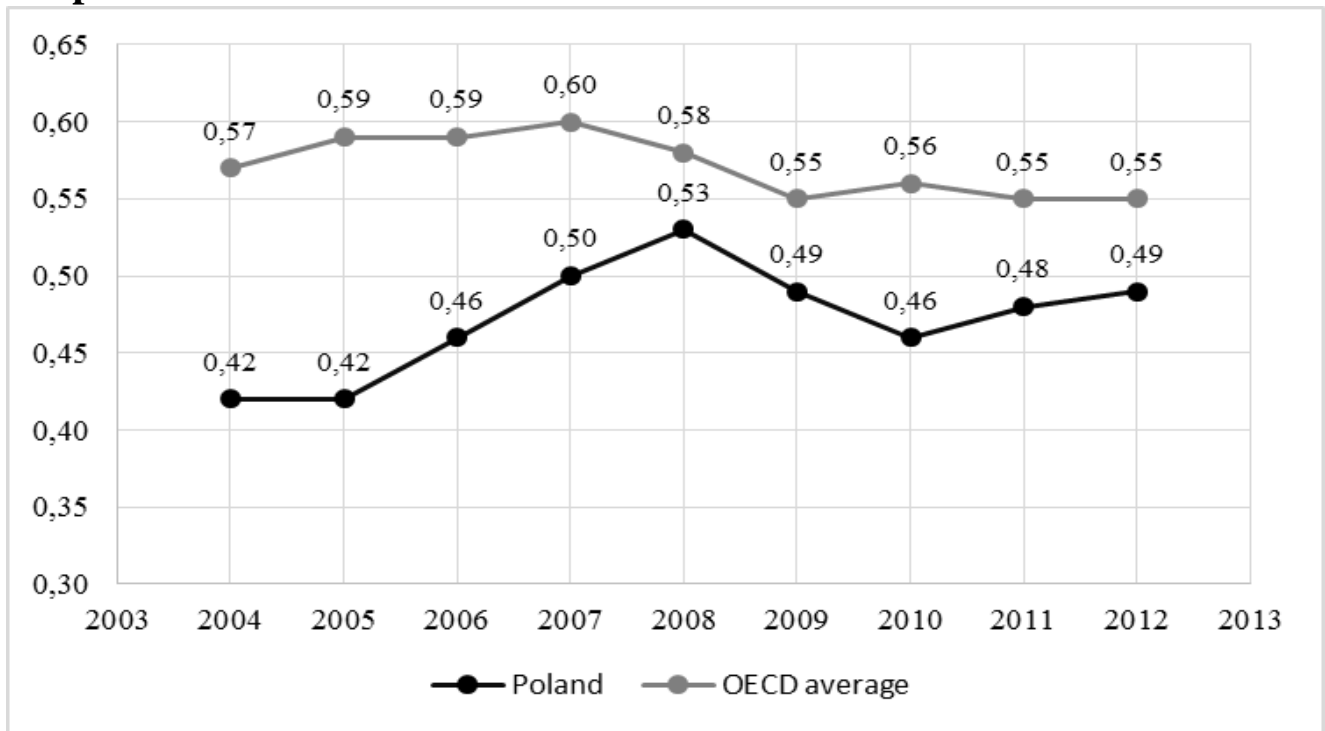

Source: Own work based on OECD (2014).

One of the reasons for which the VRR in Poland is low is that in Poland there are two reduced VAT rates used. Not only using reduced rates makes it more difficult for taxpayers to fulfill their tax obligations and gives incentives to tax evasion, but it also reduces the tax revenue. In 2012 the amount of lost revenue caused by using reduced tax rates in VAT was estimated to PLN 42.5 bln, which is almost $35 \%$ of VAT revenue and $2.7 \%$ of PKB. The tax preferences in VAT aimed at families and social help amounted to PLN 25.4 bln, which is $57 \%$ of the amount (Graph 3). This includes taxing food (e.g. bread and dairy products) at the rate of $5 \%$.

Graph 3. Structure of Tax Preferences in VAT in Poland in 2012

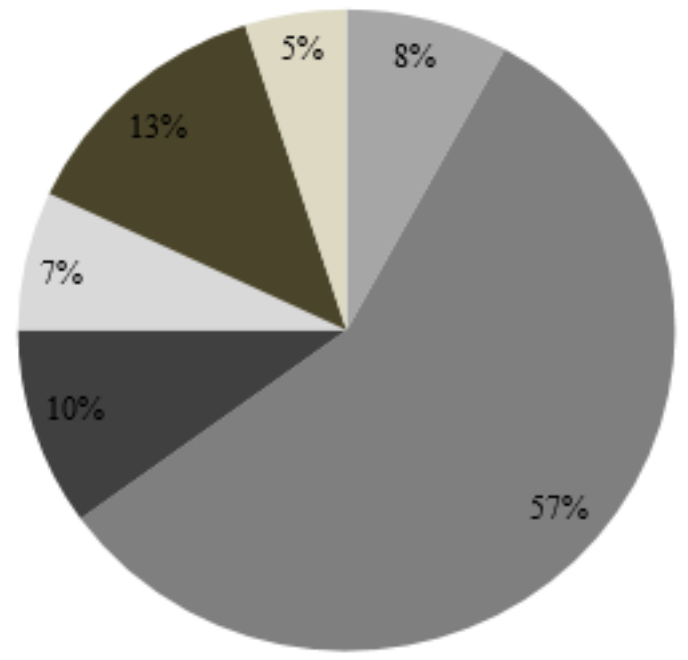

Economy

Family and social help

- Agriculture

Education

- Health

Transportation and enviromental protection

Source: Ministry of Finance of Poland, 2014. 
Moreover, in Poland there are many exemptions and the tax is not as broad-based as in countries where the VRR is much higher (e.g. New Zealand, Luxembourg, Japan, Denmark).

In order to raise the VAT efficiency the OECD suggests applying a single VAT rate. This issue has been discussed in Poland recently. The Polish Ministry of Finance proposed applying VAT at the rate of $16-17 \%$. It could help increase the VAT efficiency collection. What is more it would make it easier for taxpayers to fulfill their tax obligations as the problem of applying a correct tax rate would not exist anymore. It should be noted that applying a single VAT rate is not a popular solution among European Union countries (European Commission 2007). There is only one country which does not use reduced rates, which is Denmark with VAT at a rate of $25 \%$. The VRR in Denmark is higher than the OECD average, which may suggest that the application of single VAT rate has a positive impact on the VRR.

\section{Conclusion}

Value added tax has become a pivotal source of revenue in most countries around the world. Since it has not been researched as thoroughly as income taxes yet there is a need to focus on VAT. The article presented the basis of functioning of VAT in Poland. It has been shown that even though the VAT is harmonized within the European Union there are many differences in case of design issues of the tax. It has been proved that the Polish standard VAT rate is among the highest in the EU. The average VAT rate for the EU in 2015 was $21.6 \%$, i.e. $1.4 \mathrm{pp}$ less than in Poland. It has been also shown that the VAT arrangements to small enterprises used in Poland include subject exemptions and quarterly settlements and are considered relatively narrow in scope as compared to other EU countries.

In the article the VAT revenue to government revenue ratio has been examined and compared with other European countries. In years 2004-2012, the VAT revenue to tax revenue ratio in the EU was $31.1 \%$ on a yearly average. The ratio level for Poland was usually above the EU average. Moreover, using VRR as a measure it has been proved that during the analyzed period a significant amount of potential VAT was not collected. The VRR in Poland was lower than the EU and OECD average. It suggests that there is a potential for raising additional revenue by improving the VAT performance in Poland. One of the reasons for which the VRR in Poland is low is that in Poland there are two reduced VAT rates used. In 2012 the amount of lost revenue caused by using reduced tax rates in VAT was estimated to PLN 42.5 bln, which is almost $35 \%$ of VAT revenue and $2.7 \%$ of PKB. One of the ways of improving VAT performance in Poland is to apply a single VAT rate. 


\section{References}

Borselli F (2011) Organized VAT fraud: features, magnitude, policy perspectives. Retrieved from http://goo.gl/z2KHvX.

Cnossen S (1991) Design of the Value-Added Tax: Lessons from Experience. Washington: World Bank.

Ebrill L, Keen M, Bodin JP, Summers V (2001) The modern VAT. Washington: International Monetary Fund.

European Commission. 2015. VAT rates applied in the Member States of the European Union, Retrieved from http://goo.gl/lyrM7u.

Głuchowski J (2004) Polskie prawo podatkowe (Polish tax law). Warszawa: Wydawnictwo Prawnicze Lexis-Nexis.

Hybka M (2013) Szczególne procedury rozliczania podatku od wartości dodanej przez matych przedsiębiorców w Polsce, Niemczech i Wielkiej Brytanii (Simplified VAT procedures for small enterprises in Poland, Germany and United Kingdom). Science Notebooks no. 752, Szczecin, Poland.

Keen M (2013) The Anatomy of the VAT. Working Paper no. 13/111. Washington: International Monetary Fund.

Ministry of Finance of Poland. 2014. The Tax Preferences in Poland, Ministry of Finance, Poland.

OECD (2014) The consumption tax trends. Paris: OECD.

OECD (2012) The consumption tax trends. Paris: OECD.

Schenk A, Oldman O (2007) Value added tax. New York: Cambridge University Press.

Sullivan CK (1965) The tax on value added. New York and London: Columbia University Press.

Supreme Audit Office (NIK) (2004-2012) Analiza wykonania budżetu państwa $i$ założeń polityki pieniężnej $w$ latach 2004-2012 (Analysis of state budget and monetary policy delivery in years 2004-2012), Warsaw.

VAT Act - the Polish Value Added Tax Act. Retrieved from http://goo.gl/DPrxRN (in Polish).

VATLive. Retrieved from http://goo.gl/Tb71Zr. 